\title{
Nutraceutical Properties of Apples and Derived Products (Pomace, Seeds, Peels)
}

\begin{abstract}
GABRIELA PLOSCUTANU', ALINA MIHAELA ELISEI2*, OLIMPIA DUMITRIU BUZIA²
'Dunarea de J os University of Galati, Faculty of Food Science and Engineering, 111, Domneasca Str., 800201, Galati, Romania 2Dunarea de J os University of Galati, Faculty of Medicine and Pharmacy, Research Center in the Field of Medical and Pharmaceutical Sciences, Pharmaceutical Sciences Department, 35 Al. I. Cuza Str., 800010, Galati, Romania

Because of multiple benefits for human health, apple polyphenols have attracted significant attention in the scientific field. This review is a compilation of the polyphenolic profile of apple and apple derived products. This approach may represent an environment-friendly alternative for the revalorization of the apples derived products, generated in excessive amounts by the industrial production of juice, ciders, vinegar. In conclusion, our results demonstrate that the total phenolic content varies considerably in fresh apples and products resulted from their processing, influencing their nutraceutical properties.
\end{abstract}

Keywords: apple, juice, cider, pomace, polyphenols

\section{Secondary metabolites}

Apples are well-known and widespread fruit of the genus Malus (about25 species) belonging to the family Rosaceae. Apples (Malus domestica Borkh) are commonly consumed as unprocessed fresh fruit, and fresh apples are available worldwide all year round [54].

Apple production is one of the most widespread agrifood activities worldwide, with an estimated volume of USD 76.2 million tonnes in 2017/18 [60]. An important part of this production is destined to elaborating juice and derivatives such as soft drinks, ciders, vinegars etc. [48].

Secondary metabolites are natural chemical compounds that plants produce to protect themselves against other living and natural conditions. Phenolic compounds are the mostimportant secondary compounds of the derivatives of pentose phosphate, shikimate and phenylpropanoid pathways in plants and are the most abundant compounds among phytochemicals $[13,44]$. These components have biological effects such as antioxidant activity. By recycling the waste fruit pulp in the idle state, these valuable secondary metabolites will provide significant resource opportunities in terms of both the health and medicinal sectors [13]. Their use in the pharmaceutical and food-nutrition sectors is increasing due to the absence of side effects.

Polyphenols are considered as antioxidants, metal chelators, antimutagens and anticarcinogens, antimicrobial agents and clarifying agents [21]. Several factors affect the phenolic content of a fruit including variety, degree of ripeness, agricultural treatments, harvesting time and processing and storage conditions [66].

Apple polyphenols have been demonstrated to have potential beneficial effects on health, such as exhibiting antioxidant activity $[1,9,13,17,28,51]$, antibacterial effect $[3,8]$, anti-tumor properties and inhibition of carcinogenesis in skin, mammary, lung, colon etc. [9, 10, 23, 31, $50,55]$, reducing the risk of cardiovascular disease [10, $11,24,31]$, anti-inflammatory properties [26, 39], antidiabetes properties $[6,25]$ and anti-obesity effect $[36,69]$. Apple polyphenols may also have positive role on Alzheimer's disease [13]. Due to of these multiple benefits for human health, apple polyphenols attracted significant attention in the scientific field [7].

\section{The polyphenolic profile of apples}

Polyphenols are defined as substances that have an aromatic ring bearing one or more hydroxyl groups. Phenolic compounds are divided into two groups: flavonoids and phenolic acids [49].

The main classes of polyphenolic compounds identified in the apple fruitare flavanols (catechin and its derivatives), procyanidins, dihydrochalcones (phloridzin and phloretin) and phenolic acids (mainly chlorogenic), and flavonols (quercetin and its glycosides) [9,57,63].

Polyphenols are important bioactive substances in apple [7]. In the fruit, the phenolic compounds are formed during growth until the full maturity stage and they are distributed in various tissues and fractions (epicarp, mesocarp, endocarp and seeds) $[1,65]$. The distribution of phenolic compounds and antioxidant capacity in apple depending on the variety, type of tissues and the ripening stage [2]. Studies have demonstrated the distribution of phenolic compounds in ripe apples $[27,59]$. A schematic representation of concentration ranges of specific polyphenols in peel, peel and flesh and seeds is presented in figure 1 [22].

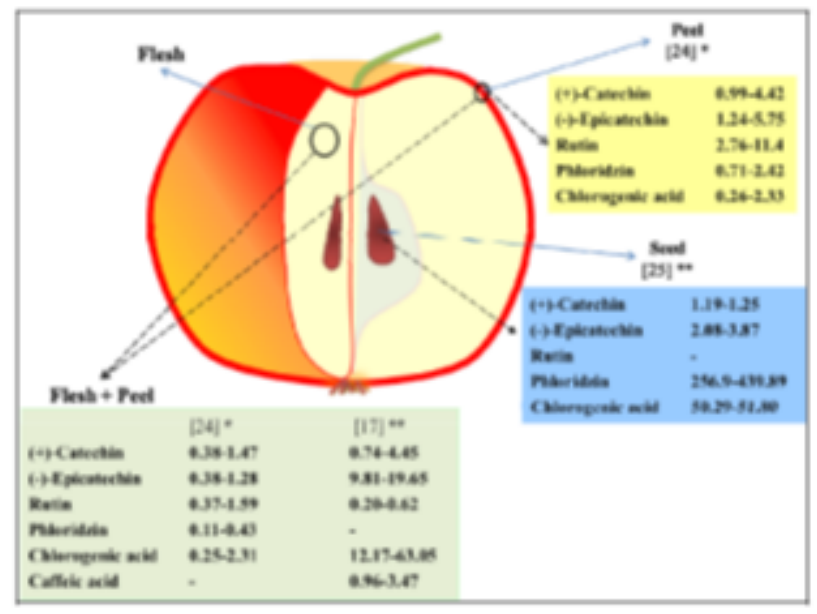

Fig. 1. Polyphenol molecule concentrations ranges in seed, peel and peel + flesh (* mg/g DW; ** $\mathrm{mg} / 100 \mathrm{~g} \mathrm{FW}$; - not measured) [22] 
Usually, epicarp is richer in phenolic compounds than the other apple tissues. Some groups of flavonoids are almost exclusively found in epicarp such as anthocyanins and flavonols (glycosides of quercetin). In other hand, monomeric and polymeric flavan-3-ols are the major phenolics of epicarp and mesocarp and can represents about $60 \%$ of the total phenolic compounds in apples. Phloridzin (dihydrochalcone) that can be used as a biomarker of apple products, are distributed in epicarp and mesocarp, as well as the hydroxycinnamic acid [17, 27, 59].

Phloridzin was found in higher amounts in the endocarp of unripe fruits that decreased with ripening and consequently, in the senescentapples, the epicarp showed higher contents. In general, phenolic acids and flavonoids decrease with ripening in the epicarp and endocarp [1].

Antioxidants are mainly localized in the apple peel, but cultivars exhibited very high biodiversity in the distribution pattern. It seems that apple peel could be a good marker of health values as well as antioxidant potential of apple fruit [29].

Each apple cultivar has its own polyphenolic profile that is also dependent on harvest year, climatic variables, cultivation and storage conditions $[62,64]$.
Whole apple fruits are processed industrially to produce juices and ciders, and therefore the contribution of these processed products to the intake of dihydrochalcones can be higher than that of the fresh apples [58].

Nine polyphenols, namely, chlorogenic acid (1), ferulic acid (2), p-coumalic acid (3), caffeic acid (4), transcinnamic acid (5), quercetin (6), rutin (7), phloridzin (8), and phloretin (9) were identified in 11 apple extracts, which comprised six cultivars from Shaanxi province, China, using the developed HPLC diode array detector method (fig. 2). Quantification was performed based on linear calibration plots of the peak areas versus the concentration. The established method could serve as a prerequisite for quality control of Mallus products [7].

\section{The polyphenolic profile of apple derived products}

Flavanones, flavanonols, chalcones, retrochalcones and dihydrochalcones are biochemically compounds found in apple derived products (fig. 3). Flavanones and flavanonols have a saturated C-ring. Chalcones and retrochalcones are unsaturated and, along with dihydrochalcones, have an open structure and a carbon skeleton numbered in a way different from other flavonoids [58].<smiles>O=C(/C=C/c1ccc(O)c(O)c1)OC1C(O)C(O)C2C(=O)OCC1C2O</smiles><smiles>O=C(O)/C=C/c1ccc(O)c(O)c1</smiles>

Caffeic acid (4)

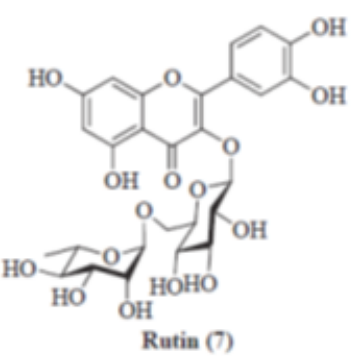<smiles>COc1cc(/C=C/C(=O)O)ccc1O</smiles><smiles>CC(C)(C)C(C)(C)C</smiles>

p-Coumalic acid (3)<smiles>O=c1c(O)c(-c2ccc(O)c(O)c2)oc2cc(O)cc(O)c12</smiles><smiles>O=C(CCc1ccc(O)cc1)c1c(O)cc(O)cc1OC1OC(O)C(O)C(O)C(O)C1(O)O</smiles><smiles>O=C(CCc1ccc(O)cc1)c1c(O)cc(O)cc1O</smiles>

Phloretin (9)<smiles>O=C1CC(c2ccc(O)cc2)Oc2cc(O)cc(O)c21</smiles><smiles>O=C(/C=C/c1ccc(O)cc1)c1c(O)cc(O)cc1O</smiles><smiles>O=C(CCc1ccc(O)cc1)c1c(O)cc(O)cc1O</smiles><smiles>O=C(/C=C/c1c(O)cc(O)cc1O)c1ccc(O)cc1</smiles>

IV
Fig. 2. Chemical structures of the identified polyphenols in apple [7]
Fig. 3. Structures and numbering systems for flavanones, dihydrochalcones, chalcones and retrochalcones: I, naringenin (flavanone); II, phloretin (dihydrochalcone); III, isosalipurpurin (chalcone); IV, retrochalcone characteristic of apples and derived products (apple juice, cider, pomace etc) [58] 
Chalcone is a precursor of dihydrochalcones; these compounds are present in apple cores and seeds, that are usually discarded when fresh apples are consumed. As whole apple fruit is processed industrially to produce juices and ciders, the contribution of these products to overall intake of chalcones can be higher than that of fresh apples [58].

Apple juices from North America (Canada and the USA), South America (Argentina, Brazil, Colombia and Paraguay) and Europe (England, France, Germany and Turkey) were assessed regarding their phenolic composition and as a result chlorogenic acid (5-0-caffeoylquinic acid) and phloridzin were found in all the samples and considered to be biomarkers in apple juices [4].

The polyphenolic content of apple juice depends on preparation method, such as possible utilisation of pectinolytic enzymes in order to release phenolic compounds from polysaccharide structures, and following treatments, such as pasteurisation, or fermentation parameters in cider production [68]. Endogenous enzymes, such as polyphenol oxidase, oxidise phenolic compounds in the apple juice and affect the sensory quality of the product [45].

Apple cider production starts with pressed apple juice. During the fruitcrushing, pressing and juice extraction only a fraction of phenolic compounds is extracted $[61,66]$. This is mainly due to the discard of the peel and seeds which are rich in different phenolic compounds [16, 22, 65].

Regarding the raw material, a set of Asturian cider apple varieties belonging to the Protected Designation of Origin Sidra de Asturias [20] has been evaluated for the production of ice juices through the assessment of their contents in sugars, acids and aromas [41]. The contents of total polyphenols in the ice juices were 2 or 3-fold the conventionally pressed apple juices [40,52].

Forty-fourAsturian ciders were analysed for total phenolic content, phenolic profiles, and antioxidant capacity by the FRAP and the DPPH radical assays. The Folin index of ciders ranged between 446 and $1180 \mathrm{mg}$ gallic acid/L. The phenolic profile of Asturian cider is mainly constituted by phenolic acids, flavan-3-ols, volatile phenols and dihydrochalcones [42].

Major polyphenols of Asturian cider are phenolic acids, dihydrochalcones and flavanols [48], which are potentially important to the antioxidant activity of cider.

Hydroxycinnamates were the predominant group of phenolics in the majority of the English ciders [34].

\section{Environment-friendly alternative for the revalorization of} apple pomace

After extraction of apple juice, large quantities of byproducts are generated, namely apple pomace, which accounts approximately to $25 \%$ of fresh apple weight [67]. Apple pomace, consisting of peel, seeds, core, stems and exhausted soft tissue, has long been recognised as a valuable material for nutritional, pharmacological or cosmetic purposes, as it is rich in dietary fibre and polyphenols $[33,53]$.

Different studies have been carried out on the composition and properties of apple pomace revealing it as an interesting raw material due to its content in nutrients, phytochemicals and functional components, reevaluating this waste as a nutritive and functional foodstuff, besides being an important source of pectins and fibre [48].

A broad range of applications have been described for apple pomace, namely: scaffold for tissue engineering [67], bioproduction of enzymes, organic acids, biofuels [14], extraction of phytochemicals, animal feed, pectin recovery [38]. These by-products have been regarded as a food additive due to their high content in polyphenols and antioxidant activity [15] and dietary fiber [35].

The beneficial effects of apple pomaces on health include the improvement of lipid metabolism; the decrease in lipid peroxidation [30], the prevention of asthma and other chronic diseases [5].

The antiviral activity found for apple pomaces suggests their potential use as a therapeutic candidate for the treatment of herpetic diseases. Apple pomaces could be included in topical formulations to treat vesicular skin lesions or to prevent sexually acquired HSV infections, which strongly predispose to human immunodeficiency virus acquisition. The proven harmlessness of apple pomaces together with their high contents in antioxidant metabolites also supports their potential to be included in nutraceutical and dietary supplements or as a foodenrichment additive [15, 35].

It has been observed that native vegetable oils produced with apples seeds have antioxidant, anti-inflammatory, antiatherosclerotic, and anti-cancerous compounds related to the presence of tocochromanols, carotenoids, flavonoids, phytosterols, and phenolic acids. The extraction should be conducted with hexane and stiring at room temperature to preserve the quality of the oil. The method used for oil extraction allows pharmacological or cosmetic purposes and edible applications [43].

Apple seeds and their oils from an agro-food waste, derived from the cider industry protected by the Designation of Origin Sidra de Asturias, were chemically characterized. The average oil yield was $19.7 \%$. The major fatty acids in apple seed oils are unsaturated fatty acids belonging to the $\omega-3, \omega-6$ and $\omega-9$ series Oils also showed an important antioxidant activity and high levels of tocopherols with âtocopherol being most abundant in all cases. The results suggest apple seeds from the cider-making industry could be a suitable raw material for food, pharmacological or cosmetic uses [47].

Peeled and unpeeled apples have high antioxidant activity and inhibit the growth of human cancer cells in vitro. The antioxidantactivity as the antiproliferative activity of unpeeled apples is greater than that of peeled apples [19].

Apple peels are a waste product of applesauce and canned apple manufacture and are usually used for nonvaluable purposes.

Liu's patent (2013) claimed that apple peel powder is similar to fresh apple peel with regard to phytochemical characteristics: the phenolic content, flavonoid content, antioxidant activity, and/or antiproliferative activity. Apple peel powder can be used as a dietary supplement to a cancer patient under circumstances that can treat cancer. The apple peel pow der should be administered in a single unit dosage that comprises enough substance to treat cancer. It can be accompanied by excipients or stabilizers and could be solid or liquid in the form of tablets, capsules, powders, solutions, suspensions or emulsions. Oral administration is possible with the apple peel powder combined with any proper excipients or stabilizers and administered alone or in a composition. It can be a solid, a solution or a suspension in liquid form [32].

Solid forms of the apple peel powder could be of ordinary type such as capsules, possibly normal gelatin types made of the powder and carriers like lubricants and inert fillers. Another form would be tableted with ordinary tablet bases like lactose, sucrose or cornstarch combined with acacia or gelatin as binders and disintegrating agents like 
cornstarch, potato starch, or alginic acid and stearic acid or magnesium stearate as lubricant. The apple peel powder can be administered combined with different therapeutic regimens [32].

A different aspect claimed by Liu's patent is providing a way to inhibit proliferation of the cancer cells by contacting cancer cells with apple peel powder under circumstances able to inhibit the spreading of cancer cells [32].

\section{Conclusions}

Fresh apples and products from their processing should be regarded as a valuable product based on their potential as a functional food or value-added ingredient in the future. Extended research should be conducted to establish their use in medicine, health, food, cosmetics and other sectors for the benefits of consumers.

It is useful, under specific circumstances, that new substances - perhaps plant derived products of limited adverse reaction potential - and non-aggressive alternative treatments to be investigated and used [ $18,37,46,56]$ for the prevention and management of chronic diseases. is well known today to use pharmaceuticals with retarding effect in the treatment of various diseases. Using the active principles encapsulation method [abc] could lead to pharmaceutical forms that provide long-lasting action with low active powder concentrations, but with spectacular effects[70-72]

\section{References}

1. ALBERTI A., ZIELINSKI A. A. F., COUTO M., JUDACEW SKI P., MAFRA L. I., NOGUEIRA A., Distribution of phenolic compounds and antioxidant capacity in apples tissues during ripening. J. Food Sci. Technol. (2017) 54(6):1511-1518. doi: 10.1007/s13197-017-2582-z.

2. ALBERTI A., MACHADO DOS SANTOS, T. P. FERREIRA ZIELINSKI, A. A. ELEUTERIO DOS SANTOS, C. M. BRAGA, C. M. DEMIATE I. M., NOGUEIRA A., Impact on chemical profile in apple juice and cider made from unripe, ripe and senescent dessert varieties, LWT - Food Science and Technology (2016) 65:436-443. doi.org/10.1016/ j.Iwt.2015.08.045.

3. ALBERTO M. R., RINSDAHL CANAVOSIO M. A., MANCA DE NADRA M. C., Antimicrobial effect of polyphenols from apple skins on human bacterial pathogens, Electron. J. Biotechnol., (2006) 9(3). DOI: 10.2225/ vol9-issue3-fulltext-1.

4. ALVAREZ, L. V. H., ZIELINSKI, A. A. F., ALBERTI, A., NOGUEIRA, A., Monitoring of the phenolic compounds and in vitro antioxidant activity of apple beverages according to geographical origin and their type: A chemometric study, LWT- Food Science and Technology (2017) 84:385393. doi.org/10.1016/j.Iwt.2017.05.078.

5. ALVAREZ A. L., MELO S., DALTON K. P., NICIEZA I., ROQUE A., SUÁREZ B., PARRA F., Apple Pomace, a By-Product from the Asturian Cider Industry, Inhibits Herpes Simplex Virus Types 1 and 2 In Vitro Replication: Study of Its Mechanisms of Action, J. Med. Food (2012) 15(6):581-587. DOI: 10.1089/jmf.2011.0308.

6. BABU P V. A., LIU D., GILBERT E. R., Recent advances in understanding the anti-diabetic actions of dietary flavonoids, J. Nutr. Biochem. (2013) 24:1777-1789. doi:10.1016/j.jnutbio.2013.06.003.

7. BAI L., GUO S., LIU Q., CUI X., ZHANG X. ZHANG L., YANG X., HOU M., HO C. T., BAI N., Characterization of nine polyphenols in fruits of Malus pumila Mill by high - performance liquid chromatography. J. Food Drug Anal., (2016) 24 (2):293-298. doi.org/10.1016/ j.jfda.2015.10.002.

8. BEHERA S., KHETRAPAL P., PUNIA K.S., AGRAWAL D., KHANDELVAL M., LOHAR J., Evaluation of Antibacterial Activity of Three Selected Fruit Juices on Clinical Endodontic Bacterial Strains, J. Pharm., Bioallied. Sci., (2017) 9(1): S217-S221. doi:10.4103/jpbs.JPBS_164_17. 9. BIEDRZYCKA E., AMAROWICZ R., Diet and health: Apple polyphenols as antioxidants, Food Rev. Int. (2008) 24(2):235-251. doi.org/10.1080/87559120801926302.
10. BOYER J., LIU RUI H., Apple phytochemicals and their health benefits, Nutrition J ournal, (2004) 3:1-15. doi.org/10.1186/1475-2891-35.

11. CHAI S. C., HOOSHMAND S., SAADAT R. L. PAYTON M. E., BRUMMEL-SMITH K., ARJ MANDI B. H., Daily apple versus dried plum: impact on cardiovascular disease risk factors in postmenopausal women, J. Acad. Nutr. Diet., (2012) 112(8):1158-1168. doi: 10.1016/ j.jand.2012.05.005.

12.CHAN A., SHEA T, Dietary supplementation with apple juice decreases endogenous amyloid-beta levels in murine brain, J. Alzheimers Dis., (2009) 16(1):167-71. doi: 10.3233/J AD-2009-0959

13.DEMIRCI M. A., IPEK Y., GUL F., OZEN T., DEMIRTAS I,, Extraction, isolation of heat-resistance phenolic compounds, antioxidant properties, characterization and purification of 5-hydroxymaltol from Turkish apple pulps, Food Chem. (2018) 269:111-117. doi.org/10.1016/ j.foodchem.2018.06.147.

14. DHILLON G. S., KAUR S., BRAR S. K., Perspective of apple processing wastes as low cost substrates for bioproduction of high value products: a review, Renew. Sustain. Energy. Rev. (2013) 27: 789805. doi.org/10.1016/j.rser.2013.06.046.

15.DIÑEIRO Y., SUÑREZ B., PICINELLI A., Phenolic and antioxidant composition of by-products from the cider industry: apple pomace, Food Chem. (2009) 117:731-738. doi:10.1016/j.foodchem.2009.04.049. 16.DROGOUDI P. D., MICHAILIDIS Z., PANTELIDIS G., Peel and flesh antioxidant content and harvest quality characteristics of seven apple cultivars, Sci. Hortic., (2008) 115: 149-153. https://doi.org/10.1016/ j.scienta.2007.08.010.

17.DUDA-CHODAK A., TARKO T., TUSZYNSKI T., Antioxidant activity of apples - an impact of maturity stage and fruit part, Acta. Sci. Pol. Technol. Aliment. (2011) 10:443-454.

18.DUMITRIU, B.O., FASIE, V., MARDARE, N., DIACONU, C., GURAU,G.,TATU, A. L., Formulation, Preparation, Physico-chimical Analysis, Microbiological Peculiarities and Therapeutic Challenges of Extractive Solution of Kombucha, Rev. Chim.(Bucharest), 69, no. 3, 2018, p.720-24

19.EBERHARDT M.V., LEE, C.Y., LIU R.H. Antioxidant Activity of Fresh Apples, Nature (2000) 405: 903-904. DOI:10.1038/35016151.

20.*** EC 2154/2005. Commission Regulation No 2154/2005 of December 23rd supplementing the Annex to Regulation No 2400/96 as regards the entry of a name in the Register of Protected Designation of Origin and Protected Geographical Indications (Sidra de Asturias). 21. EL GHARRAS H., Polyphenols: food sources, properties and applications - a review, Int. J. Food Sci. Technol., (2009) 44(12):25122518. doi.org/10.1111/j.1365-2621.2009.02077.x.

22.FRANCINI A., SEBASTIANI L., Phenolic compounds in apple (Malus $x$ Domestica Borkh.): Compounds characterization and stability during postharvest and after processing, Antioxidants (2013) 2(3):181-193. doi.org/10.3390/antiox2030181.

23. J EDRYCHOW SKI W., MAUGERI U., PAC A., SOCHACKA T. E., GALAS A., Reduced risk of colorectal cancer and regular consumption of apples: hospital based case-control study in Poland, Cent. European J. Med., (2009) 4:320-326. DOI: 10.2478/s11536-009-0033-6\}.

24.J OSHIPURA K. J., HU F. B., MANSON J. E., STAMPFER M. J ., RIM E. B., SPEIZER F. E., COLDITZ G., ASCHERIA A., ROSNER B., SPIEGELMANA D., WILLETT W. C., The effect of fruit and vegetable intake on risk for coronary heart disease, Ann. Intern. Med., (2001) 134:1106-1114.DOI: 10.7326/0003-4819-134-12-200106190-00010.

25.JUN S., SHIN S., J OUNG H., Estimation of dietary flavonoid intake and major food sources of Korean adults, Br. J. Nutr. (2016) 115:480489.doi: 10.1017/S0007114515004006.

26.JUNG M., TRIEBEL S., ANKE T., RICHLING E., ERKEL G., Influence of apple polyphenols on inflammatory gene expression, Mol. Nutr. Food Res., (2009) 53(10):1263-80. doi: 10.1002/mnfr.200800575.

27.KALINOWSKA M., BIELAWSKA A., LEWANDOWSKA-SIWKIEWICZ H., PRIEBE W., LEWANDOWSKI W., Apples: content of phenolic compounds vs. variety, part of apple and cultivation model, extraction of phenolic compounds, biological properties, Plant. Physiol. Bioch. (2014) 84:169-188. doi:10.1016/j.plaphy.2014.09.006. 
28.KHANIZADEH S., TSAO R., REKIKA D., YANG R., CHARLES M. T., RUPASINGHE H. P. V., Polyphenol composition and total antioxidant capacity of selected apple genotypes for processing. J. Food Compost. Anal. (2008) 21:396-401 doi.org/10.1016/j.jfca.2008.03.004.

29.LATA B., Relationship between apple peel and the whole fruit antioxidant content: year and cultivar variation, J. Agric. Food Chem., (2007) 55(3):663-671. DOI: 10.1021/jf062664j

30.LEONTOWICZ H., GORINSTEIN S., LOJEK A., LEONTOWICZ M.., CIZ M., SOLIVA-FORTUNY R., PARK Y. S., JUNG S. T., Trakhtenberg S, Martin-Belloso 0: Comparative content of some bioactive compounds in apples, peaches and pears and their influence on lipids and antioxidant capacity in rats, J. Nutr. Biochem., (2002) 13:603-610. doi.org/10.1016/S0955-2863(02)00206-1.

31.LIU R. H., Health benefits of fruit and vegetables are from additive and synergistic combinations of phytochemicals, Am. J. Clin. Nutr., (2003) 78(3Suppl): 517S-520S. doi.org/10.1093/ajcn/78.3.517S.

32.LIU R. H., United States Patent no. 008551554 B2 - Apple peel powder, methods of making, and uses thereof (2013) Available at: https://patentimages.storage.googleapis.com/a6/0b/05/a4286ea6f6bbc4/ US20050147723A1.pdf.

33.LU Y., YEAP FOO L., Antioxidant and radical scavenging activities of polyphenols from apple pomace, Food Chem., (2000) 68:81-85. doi.org/10.1016/S0308-8146(99)00167-3.

34.MARKS S. C., MULLEN W., CROZIER A., Flavonoid and hydroxycinnamate profiles of English apple ciders, J. Agric. Food Chem., (2007) 55(21):8723-8730. doi.org/10.1021/jf071155u.

35.MASOOI F. A., SHARMA B., CHAUHAN G. S., Use of apple pomace as a source of dietary fiber in cakes, Plant. Foods Hum. Nutr., (2002) 57:121-128. doi.org/10.1023/A:1015264032164.

36.MOHAMED G. A., IBRAHIM S. R. M., ELKHAYAT E. S., EL DINE R. S., Natural anti-obesity agents, Bull. Fac. Pharm. Cairo Univ. (2014) 52, 269-284. doi.org/10.1016/j.bfopcu.2014.05.001.

37.NWABUDIKE, L. C., ELISEI, A. M., BUZIA, O. D., MIULESCU, M., TATU, A. L., Statins. A Review on Structural Perspectives, Adverse Reactions and Relations with Non-melanoma Skin Cancer, Rev. Chim.(Bucharest), 69, no. 9, 2018, p. 2557-2562

38.0'SHEA N., ARENDT E. K., GALLAGHER E., Dietary fibre and phytochemical characteristics of fruit and vegetable by-products and their recent applications as novel ingredients in food products, Innovat. Food. Sci. Emerg. Technol., (2012) 16:1-10. DOI: 10.1016/ j.ifset.2012.06.002.

39.PADUA T. A., DE ABREU B. S. NAKAMURA M. J. VALENTE L. M., HENRIQUES M., SIANI A. C., ROSASE. C., Anti-inflammatory effects of methyl ursolate obtained from a chemically derived crude extract of apple peels: potential use in rheumatoid arthritis, Arch. Pharm. Res., (2014) 37(11):1487-95. doi: 10.1007/s12272-014-0345-1.

40.PANDO BEDRINANA R., PICINELLI LOBO A., SUAREZ VALLES B., Influence of the method of obtaining freeze-enriched juices and year of harvest on the chemical and sensory characteristics of Asturian ice ciders, Food Chem., (2019) 274:376383. doi.org/10.1016/ j.foodchem.2018.08.141.

41.PICINELLI LOBO A., ANTON-DIAZ M. J., PANDO BEDRINANA R., FERNANDEZ GARCIA O., HORTAL-GARCIA R., SUÁREZ VALLES B. Chemical, olfactometric and sensory description of single-variety cider apple juices obtained by cryo-extraction, LWT- Food Science and Technology, (2018) 90:193-200. DOI: 10.1016/j.Iwt.2017.12.033.

42.PICINELLI LOBO A., DIOEIRO GARCIÁ Y., MANGAS SANCHEZ J., RODRÍGUEZ MADRERA R., SUAREZ VALLES B., Phenolic and antioxidant composition of cider, J. Food Compost. Anal.. (2009) 22(78):644-648. doi:10.1016/j.jfca.2009.03.008.

43.PIESZKA M., MIGDAL W., G¥SIOR R., RUDZINSKA M., BEDERSKA fOJ EWSKA D., PIESZKA M., SZCZUREK P., Native oils from apple, blackcurrant, raspberry and strawberry seeds as a source of polyenoic fatty acids, tocochromanols and phytosterols - a health implication, J. Chem., (2015) 1-8. doi.org/10.1155/2015/659541.

44.PIRLAK L., ÜNÜVAR G., ERSOY N., Determination of antioxidant activities of some apple cultivars, Hort. Sci., (2017) 44(3):120-125. doi.org/10.17221/276/2015-HORTSCI.
45.RENARD C. M. G. C., LE QUERE J. M., BAUDUIN R., SYMONEAUX R., LE BOURVELLEC C., BARON A., Modulating polyphenolic composition and organoleptic properties of apple juices by manipulating the pressing conditions, Food Chem., (2011) 124(1):117125. http://dx.doi.org/10.1016/j.foodchem.2010.05.113|

46.ROBU S., CHESARU B. I., DIACONU C., DUMITRIU B. O., TUTUNARU D., STANESCU, U., LISA, E. L.,Lavandula hybrida: microscopic characterization and the evaluation of the essential oil Farmacia, (2016) vol. 64, 6.914-917

47.RODRIGUEZ MADRERA R., SUAREZ VALLES B., Characterization of apple seeds and their oils from the cider-making industry, Eur. Food Res. Technol., (2018) 244:1821-1827. doi.org/10.1007/s00217-018-30944.

48.RODRIGUEZMADRERA R., PANDO BEDRIÑANA R., SUÁREZ VALLES $B$., Enhancement of the nutritional properties of apple pomace by fermentation with autochthonous yeasts. LWT- Food Science and Technology, (2017) 79:27-33. DOI, 10.1016/j.Iwt.2017.01.021.

49.SHAHIDI F., NACZK M., (eds.) , Phenolics in Food and Nutraceuticals. CRC Press LLC, (2004) Available at: http://dl.taq.ir/science/ phenolics_in_food_and_nutraceuticals_shahidi.pdf.

50.SHAO J. W., DAI Y. C., XUE J. P., WANG J. C., LIN F. P., GUO Y. H., In vitro and in vivo anticancer activity evaluation of ursolic acid derivatives. European J. Med. Chem., (2011) 46:2652-2661

51.SPENCER J. P., EL MOHSEN M. M. A.,MINIHANE A. M., MATHERS J. C., Biomarkers of the intake of dietary polyphenols: strengths, limitations and application in nutrition research, Br. J. Nutr., (2008) 99(1):12-22, doi.org/10.1017/S0007114507798938.

52.SUAREZ VALLES B., PANDO BEDRIÑANA R., FERNANDEZ TASCÓN N., GONZALEZ GARCÍA A., RODRIGUEZ MADRERA R., Analytical differentiation of cider inoculated with yeasts (Saccharomyces cerevisiae) isolated from Asturian (Spain) apple juices, LWT-Food Science and Technology. (2005) 38:455-461 doi:10.1016/j.Iwt.2004.07.008. 53. SUDHA M. L., BASKARAN V., LEELAVATHI K., Apple pomace as a source of dietary fiber and polyphenols and its effects on rheological characteristics and cake making, Food Chem., (2007) 104:686-692. doi.org/10.1016/j.foodchem.2006.12.016.

54. SUGIURA T., OGAWA H, FUKUDA N,. MORIGUCHI T., Changes in the taste and textural attributes of apples in response to climate change, Sci.. Rep., (2013) 3:1-7. DOI: 10.1038/srep02418.

55.SUN J ., CHU Y. F., WU X., LIU R. H., Antioxidant and Antiproliferative Activities of Common Fruits, J. Agric. Food Chem., (2002) 50:74497454. doi.org/10.1021/jf0207530.

56.TATU, A. L., CIOBOTARU, O. R., MIULESCU, M., BUZIA, O. D., ELISEI, A. M., MARDARE, N., DIACONU, C., ROBU, S., NWABUDIKE, L. C., Hydrochlorothiazide: Chemical Structure, Therapeutic, Phototoxic and Carcinogenetic Effects in Dermatology, Rev. Chim.(Bucharest), 69, no. 8, 2108, p. 2110-2114

57.THOMPSON-WITRICK K. A., GOODRICH K. M., NEILSON A. P., HURLEY E. K., PECK G. M., STEWART A. C., Characterization of the polyphenol composition of 20 cultivars of cider, processing, and dessert apples (Malus domestica Borkh.) grown in Virginia, J ournal of Agricultural and Food Chemistry (2014) 62(41):10181-10191. doi.org/ 10.1021/j503379t.

58.TOMAS-BARBERAN F. A., CLIFFORD M. N., Flavanones, chalcones and dihydrochalcones - nature, occurrence and dietary burden, J. Food Sci Agric., (2000) 80(7):1073-1080. doi.org/10.1002/(SICI)10970010(20000515)80:7<1073::AID-J SFA568> 3.0.CO;2-B.

59.TSAO R., YANG R., YOUNG J. C., ZHU H, Polyphenolic profiles in eight apple cultivars using high-performance liquid chromatography (HPLC), J. Agric. Food Chem., (2003) 51(21):6347-6353. doi:10.1021/ jf0346298.

60.*** USDA Foreign Agricultural Service (2017) https://apps.fas. usda.gov/psdonline/circulars/fruit.pdf.

61.VAN DER SLUIS A. A., DEKKER M., VAN BOEKEL M. A. J. S., Activity and concentration of polyphenolic antioxidants in apple juice. Stability during storage, J. Agric. Food Chem., (2005) 53(4): 1073-1080 doi.org/ 10.1021/jf040270r. 
62.VAN DER SLUIS A. A., DEKKER M., DE JAGER A., JONGEN W. M. F., Activity and concentration of polyphenolic antioxidants in apple: effect of cultivar, harvest year, and storage conditions, Agric. Food Chem., (2001) 49(8):3606-3613. DOI: 10.1021/f001493u.

63.VERDU C. F., CHILDEBRAND N., MARNET N., LEBAIL G., DUPUIS F., LAURENS F., GUILET D., GUYOT S., Polyphenol variability in the fruits and juices of a cider apple progeny, J Sci. Food Agric., (2014) 94(7):1305-1314. doi.org/10.1002/jsfa.6411.

64.ZARDO D. M., SILVA K. M., GUYOT S., NOGUEIRA A., Phenolic profile and antioxidant capacity of the principal apples produced in Brazil, Int J. Food Sci. Nutr. (2013) 64(5):611-620. doi: 10.3109/ 09637486.2013.763909.

65.ZHANG Y., LI P., CHENG L., Developmental changes of carbohydrates, organic acids, amino acids, and phenolic compounds in 'Honeycrisp' apple flesh. Food Chem., (2010) 123(4):1013-1018. doi:10.1016/j.foodchem.2010.05.053

66. ZIELINSKI A. A. F., ALBERTI A., BRAGA C. M., SILVA K. M., CANTERI M. H. G., MAFRA L. I., GRANATO D., NOGUEIRA A., WOSIACKI G., Effect of mash maceration and ripening stage of apples on phenolic compounds and antioxidant power of cloudy juices: a study using chemometrics, LWT - Food Science Technology, (2014) 57(1):223-229. doi: 10.1016/j. Iwt.2014.01.02.
67.YATES M., GOMEZ M. R., MARTIN-LUENGO M. A., IBAÑEZ, V. Z., MARTINEZ SERRANO A. M., Multivalorization of apple pomace towards materials and chemicals. Waste to wealth, J. Clean. Prod., (2017) 143:847-853 doi.org/10.1016/j.jclepro.2016.12.036.

68.YE M., YUE T., YUAN Y., Changes in the profile of volatile compounds and amino acids during cider fermentation using dessert variety of apples, Eur. Food Res. Technol., (2014) 239(1):67-77, doi.org/10.1007/ s00217-014-2204-1.

69.YUTAKA O., MANABU S.,TOMOMASA K.,, KENJI S., KYOICHI O., HISANORI K., Anti-obesity Effect by Apple Polyphenols in Rats Fed a High Fat Diet or a Normal Diet, J. Oleo. Sci., (2006) 55(6):305-314. DOI: 10.5650/jos.55.305.

70.DUMITRIU, B.O., MARDARE, N., DIACONU, C., The Study of Nystatin Release from Microcapsules Obtained by lonotropic Gelation, Rev. Chim.(Bucharest), 67, no.2, 2016, p. 232-235

71.DUMITRIU B.O, DIMA C., DIMA S., Preparation and characterization of chitosan microspheres for vancomycin delivery, Farmacia, 2015, vol. $63,6,897-902$

72.DUMITRIU B.O,DIMA S.,Biopolymer-based Techniques for Encapsulation of Phytochemicals Bioacive in Food and Drug,Revista de materiale plastice,53,No.1,2016,126-12

$\overline{\text { Manuscript received: } 21.12 .2018}$ 